\title{
Engagement in Tourism and Personality Traits among Ukrainian Adolescents
}

\author{
Nicholas Hryhorczuk*, Alexander Zvinchuk, Zoreslava Shkiriak-Nyzhnyk, Ludmila Slobodchenko, Alla Matsola, Daniel \\ Hryhorczuk
}

\begin{tabular}{|c|c|}
\hline & ABSTRACT \\
\hline Keywords: & The aim of this paper was to determine if there is an association between personality traits and \\
\hline Tourism & engagement in tourism among Ukrainian adolescents. The study population consisted of 1075 \\
\hline Personality & adolescents and their mothers/caregivers who participated in the Family and Children of Ukraine birth \\
\hline Ukraine & cohort study. The adolescents self-reported how they prefer to spend their leisure time and also completed \\
\hline Adolescent & $\begin{array}{l}\text { the revised Eysenck Personality Inventory (EPI). We found that engagement in tourism was } \\
\text { significantly associated with better school performance and higher socioeconomic status. Adolescents } \\
\text { who engage in tourism also had significantly higher Extraversion and lower Neuroticism scores on the } \\
\text { EPI. The associations of tourism engagement with these personality traits remained significant after }\end{array}$ \\
\hline & adjusting for age, gender, socioeconomic status, and school performance. We conclude that personality \\
\hline & traits are important predictors of Ukrainian adolescents' engagement in tourism. \\
\hline
\end{tabular}

Accepted: 13.11.2019

Doi: https://doi.org/10.31822/jomat.580446

\section{Introduction}

Understanding personality can provide important insights into tourist behavior. Personality can affect people's choice of leisure activity, decisionmaking processes, emotions, and interaction with others (Leung and Law, 2010). Personality traits, especially extraversion and neuroticism, are also strong predictors of life satisfaction (Schimmack et al, 2004). Noyan (2017) studied how personality traits influence both choice of leisure activity and life satisfaction. They found that leisure behavior has a strong influence on life satisfaction and that this relationship in mediated in part by the personality traits of the individual. They also point out that despite leisure activity being subject to individual choice, many people fail to engage in activities that give them satisfaction. This can be especially true for adolescents, whose choice can be influenced by parents and peers. Pizam et al. (2004) were among the first to look at questions of personality and tourist behavior among adolescent populations. They studied university students in
11 different countries and confirmed that the personality characteristics of risk-taking and sensation-seeking are associated with specific travel behaviors of young adults. Furthermore, they determined that these behaviors can also be affected by a person's nationality and culture.

Previous investigators have studied the associations of personality traits and tourism behavior in different populations around the world using a variety of scales. The main personality scales that have been previously applied to tourism research include the Eysenck personality scales, the Plog psychocentric/allocentric scale, and Zuckerman's sensation seeking scale (Eysenck, 1969; Plog, 1972; Zuckerman, 1979). Hans and Sybil Eysenck developed the Eysenck Personality Inventory (EPI) to measure personality traits of extraversion/introversion and neuroticism/stability. The test contains 57 yes-no items with no repetition of items. The EPI reveals 3 scores: the lie score, the extraversion (E) score, and the neuroticism (N) score. The EPI was

\footnotetext{
\begin{tabular}{rr}
\hline * Corresponding Author & Research Paper \\
\hline Nicholas Hryhorczuk & PhD, Northern Illinois University, USA, Email: nhryhorczuk@niu.edu, Orcid Id: 0000-0001-7403-0008
\end{tabular}

Alexander Zvinchuk MS, Institute of Pediatrics, Obstetrics, and Gynecology, Ukraine, Email: zvinchuk@hotmail.com, Orcid Id: 0000-0001-7163-1932

Zoreslava Shkiriak-Nyzhnyk MD, Sc.D, Institute of Pediatrics, Obstetrics, and Gynecology, Ukraine, Email: zoreslava7@ukr.net, Orcid Id:0000-0002-4703-2427

Ludmila Slobodchenko M.Psych, Institute of Pediatrics, Obstetrics, and Gynecology, Ukraine, Email: vpz10@ukr.net, Orcid Id:0000-0002-4560-7434

Alla Matsola MS, M.Psych, Institute of Pediatrics, Obstetrics, and Gynecology, Ukraine, Email: allamatsola@ gmail.com, Orcid Id:0000-0002-5447-571X

Daniel Hryhorczuk MD, MPH, University of Illinois College of Medicine, USA, Email: dhryhorc@uic.edu, Orcid Id: 0000-0001-7625-6756
} 
followed by the Eysenck Personality Questionnaire (EPQ) which introduced psychoticism as a third dimension to the original two-pronged model.

Plog (1972) was the first to classify tourists based on their psychographic characteristics: psychocentric to allocentric. The model was designed to match people and places with their psychographic characteristics which jumpstarted the merger between psychology and tourism research. According to Plog's scale, allocentrics prefer less developed destinations and independent vacations, while psychocentrics prefer to travel with groups to more developed destinations. The implications were both theoretical and economic. Hoxter and Lester (1987) administered the Eysenck personality inventory together with travel experience questionnaires to 78 college students. They found the total psychocentrismallocentricism score was significantly correlated with extraversion but not with neuroticism. They also found that psychocentrics had lower neuroticism scores, which is opposite to what was predicted by Plog's model. Their results were significant for females but not for males highlighting the importance of sex differences. Other investigators have also challenged Plog's theory based on lack of data (Nickerson, 1989) and flawed methodology (Smith, 1990) among other reasons. Nickerson and Ellis (1991), McDonnell (1994), Leiper (1995) and others replicated Plog's model, but had conflicting results.

In addition to Plog's model, Zuckerman's (1979) Sensation Seeking Scale (SSS) is also widely applied to tourism research. For example, the SSS has been tested by Wang et al. (1998) in China, Roth, Schumacher, \& Brahler (2005) in Germany, and Li et al (2015) in Taiwan. Sensation seeking is a personality trait that has been linked to participation in a variety of stimulating events (Litvin, 2008), including tourist choice. In testing the relationship between risk-taking, sensation seeking, and tourist behavior, Pizam et al. (2004) found that risk-taking and sensation seeking had a significant effect on travel choices and behaviors. In psychology research, risk-taking and sensation seeking have been tied to Eysenck's (1990) Extraversion which we used in our study.

Previous research has applied these personality theories to various fields including academic performance, recreational preference, subjective well-being, and a healthy lifestyle. Poropat's (2009) meta-analysis established measures for the relationship between personality and academic performance. Kirkcady and Furnham (1991) showed extraversion to be the most powerful correlate of recreational preference. Liu's (2014) sample of 193 participants from an eastern Chinese University examined subjective well-being along with personality and leisure satisfaction. They found that extraversion was significantly positively correlated with leisure satisfaction.

Our aim was to determine how tourism engagement and psychological traits, specifically extraversion and neuroticism as measured by the revised Eysenck Personality Inventory (Eysenck and Eysenck, 1990, modified by Matolin, 1998) influence tourism behavior among Ukrainian adolescents. Previous investigators have shown that nationality and culture can modify these associations (Pizam, 2004). The choice of leisure activity is important to adolescent development and to life satisfaction. Tourism is the least popular leisure time activity among Ukrainian adolescents in Kamianske, Ukraine (Hryhorczuk et al, 2019). Understanding the predictors of tourism behavior in this population can facilitate the development of tourism in Ukraine and offer adolescents greater opportunities to pursue tourism leisure time activities that expand knowledge, promote social development, improve cultural awareness, promote health and well-being and contribute to overall life satisfaction.

\section{Methods}

\section{Study Population}

The study population consisted of 1075 adolescents and their mothers/caregivers from Kamianske, Ukraine who were enrolled in the Family and Children of Ukraine (FCOU) birth cohort study and who had also completed the FCOU 7-years-of age assessment. The FCOU study is the Ukrainian component of the European Longitudinal Study of Pregnancy and Childhood (ELSPAC). For this subcohort, we originally recruited all pregnant women from the city of Kamianske from December 1992 to June 1994, and 2156 chose to participate. 1467 completed the 3-years-of age assessment, 1417 completed the 7-years-of age assessment and of these 1075 children completed the 15 years of age assessment.

\section{Survey Instruments}

FCOU mothers/caregivers completed selfadministered questionnaires at the time of pregnancy, at birth, child's 6 months of age, 3 years of age, and 7 years of age. In 2011 we administered the 15-years-of age ELSPAC questionnaires to the 1075 adolescents and their mothers/caregivers in the current study. The self-administered questionnaires were constructed by researchers 
Table 1 Characteristics of the Study Population

\begin{tabular}{|c|c|c|c|c|c|}
\hline $\begin{array}{l}\text { Characteristics of Study } \\
\text { Population }\end{array}$ & $\mathbf{n}$ & $\%$ & $\begin{array}{l}\text { Mea } \\
\text { n }\end{array}$ & $\begin{array}{l}\text { Range } \\
\text { Min- } \\
\text { Max }\end{array}$ & SD \\
\hline CHILD'S AGE & 1075 & & 16.2 & $15.1 ; 18.2$ & 0.47 \\
\hline MOTHER'S AGE & 1075 & & 40.6 & $32.3 ; 58.8$ & 5.00 \\
\hline FATHER'S AGE & 784 & & 43.0 & $33.2 ; 65.4$ & 5.40 \\
\hline \multicolumn{6}{|l|}{ GENDER } \\
\hline Male & 543 & 50.5 & & & \\
\hline Female & 532 & 49.5 & & & \\
\hline \multicolumn{6}{|l|}{ SOCIO-ECONOMIC } \\
\hline \multicolumn{6}{|l|}{ STATUS (ADULT } \\
\hline \multicolumn{6}{|l|}{ DEFINITION) } \\
\hline Not enough money for food & 75 & 7.0 & & & \\
\hline $\begin{array}{l}\text { It is enough money for food, } \\
\text { but not for clothes }\end{array}$ & 246 & 22.9 & & & \\
\hline $\begin{array}{l}\text { It is enough money for food } \\
\text { and clothes, but not for } \\
\text { appliances }\end{array}$ & 273 & 25.4 & & & \\
\hline $\begin{array}{l}\text { It is enough for various } \\
\text { purchases, but for significant } \\
\text { acquiring we have to borrow } \\
\text { money }\end{array}$ & 249 & 23.2 & & & \\
\hline $\begin{array}{l}\text { It is enough for all things we } \\
\text { need, but we have to save to } \\
\text { buy an apartment or car }\end{array}$ & 133 & 12.4 & & & \\
\hline $\begin{array}{l}\text { It is enough money for } \\
\text { absolutely everything }\end{array}$ & 82 & 7.6 & & & \\
\hline Missing & 17 & 1.6 & & & \\
\hline \multicolumn{6}{|l|}{ SOCIO-ECONOMIC } \\
\hline \multicolumn{6}{|l|}{ STATUS (ADULT } \\
\hline \multicolumn{6}{|l|}{ DEFINITION) } \\
\hline High income & 464 & 43.2 & & & \\
\hline Low income & 594 & 55.3 & & & \\
\hline Missing & 17 & 1.6 & & & \\
\hline \multicolumn{6}{|l|}{ HOW DO YOU PERFORM } \\
\hline \multicolumn{6}{|l|}{ IN SCHOOL? } \\
\hline Very well & 77 & 7.2 & & & \\
\hline Higher than average & 234 & 21.8 & & & \\
\hline Average & 624 & 58.0 & & & \\
\hline Less than average & 113 & 10.5 & & & \\
\hline $\begin{array}{l}\text { Significantly lower than } \\
\text { average }\end{array}$ & 13 & 1.2 & & & \\
\hline Missing & 14 & 1.3 & & & \\
\hline \multicolumn{6}{|l|}{ HOW DO YOU PERFORM } \\
\hline \multicolumn{6}{|l|}{ IN SCHOOL? } \\
\hline Good performance & 311 & 28.9 & & & \\
\hline Average and below & 750 & 69.8 & & & \\
\hline Missing & 14 & 1.3 & & & \\
\hline \multicolumn{6}{|l|}{ ENGAGE IN TOURISM IN } \\
\hline YOUR SPARE TIME & & & & & \\
\hline Often or Sometimes & 307 & 28.6 & & & \\
\hline Never & 578 & 53.8 & & & \\
\hline Missing & 190 & 17.7 & & & \\
\hline
\end{tabular}

from the Institute of Pediatrics, Obstetrics, and Gynecology in Kyiv and the University of Illinois School of Public Health on the basis of similar survey instruments prepared for two other
ELSPAC study sites: Avon, UK (the ALSPAC study) and Brno, Czech Republic (current ELSPAC coordinating center). We also added the revised Eysenck Personality Inventory (EPI) as a supplement to the teenager questionnaire. All study instruments were translated from English into Ukrainian and/or Russian and reverse translated into English. The questionnaire data were entered and coded by the Louise Hamilton UIC Data Management Center in Kyiv, Ukraine. Adolescents were asked the question: "How do you spend your free time?" Adolescents who responded that they engage in tourism frequently or sometimes were compared to adolescents who said that they never engage in tourism. Data on age, gender, and performance in school were obtained from the adolescents' questionnaire. Data on current socio-economic status were obtained from the mother's/caregiver's questionnaire. Responses to individual questions on the revised Eysenck Personality Inventory were converted into summary scores for Introversion/Extraversion and Neuroticism.

\section{Statistical Analysis}

The Tourism (often and sometimes) and No Tourism (never) groups were compared on mean scores on the EPI personality scales using t tests. The trends of increasing engagement in tourism with increasing socioeconomic status and better school performance were evaluated using the test for linear trend. For subsequent analyses, socioeconomic status and performance in school were coded as a binary variable (high income vs low income) and (above average vs average and below). We calculated the relative odds with $95 \%$ confidence intervals of engagement in tourism with socioeconomic status, school performance, and engagement in other activities during their free time. The associations between the Extraversion and Neuroticism scores on the EPI and engagement in tourism were analyzed using multiple logistic regression after adjusting for age,

Table 2. Engagement in Tourism and Socioeconomic Status

\begin{tabular}{|c|c|c|c|c|}
\hline \multirow[b]{2}{*}{ SOCIOECONOMIC STATUS (Mother's Assessment) ${ }^{\mathrm{a}}$} & \multicolumn{2}{|c|}{$\begin{array}{l}\text { Often or } \\
\text { Sometimes } \\
\mathbf{N}=\mathbf{3 0 7}\end{array}$} & \multicolumn{2}{|c|}{$\begin{array}{l}\text { Never } \\
N=\mathbf{5 7 8}\end{array}$} \\
\hline & $\mathrm{N}$ & $\%$ & $\mathrm{~N}$ & $\%$ \\
\hline Not enough money for food & 12 & 20.0 & 48 & 80.0 \\
\hline Enough money for food but not for clothes & 63 & 31.3 & 138 & 68.7 \\
\hline Enough money for food and clothes, but not for appliances & 81 & 35.1 & 150 & 64.7 \\
\hline Enough for various purchases, but for significant acquiring we have to borrow money & 70 & 34.3 & 134 & 65.7 \\
\hline Enough for all things we need, but we have to save to buy an apartment or car & 47 & 45.6 & 56 & 54.4 \\
\hline Enough money for absolutely everything & 30 & 40.0 & 45 & 60.0 \\
\hline
\end{tabular}

${ }^{\mathrm{a}} \mathrm{p}=0.002$ test for trend

Source: Authors 
gender, socioeconomic status and school performance.

\section{Results}

The characteristics of the study population are presented in Table 1 . The adolescents had a mean age of 16.2 (range 15.1 to 18.2 ) and $50.5 \%$ were male. Their mother's/caregivers had a mean age of 40.6 and father's a mean age of 43.0. 307 (28.6\%) reported that they engaged in tourism often or sometimes during their free time, 578 (53.8\%) reported that they never engaged in tourism, and responses for $190(17.7 \%)$ were missing. Table 1 also presents the distribution of responses for socio-economic status (as defined by the mothers/caregivers), and adolescents' selfreporting of their school performance.

Tables 2 and 3 compare engagement in tourism with socio-economic status and school performance respectively. The percentage of children who engaged in tourism increased with increasing socioeconomic status $(p=0.002)$ and with better school performance $(\mathrm{p}<0.001)$.

Table 3. Engagement in Tourism and School Performance

\begin{tabular}{lllll}
\hline \multicolumn{1}{c}{$\begin{array}{c}\text { ENGAGE IN TOURISM } \\
\text { Often or } \\
\text { Sometimes } \\
\mathbf{N = 3 0 7}\end{array}$} & $\begin{array}{l}\text { Never } \\
\text { N=578 }\end{array}$ \\
\hline HOW WELL DO YOU & $\mathrm{N}$ & $\%$ & $\mathrm{~N}$ & $\%$ \\
PERFORM IN & & & & \\
SCHOOL & & & & \\
Very Well & 35 & 47.3 & 39 & 52.7 \\
Higher than average & 77 & 39.3 & 119 & 60.7 \\
Average & 173 & 34,7 & 326 & 65.3 \\
Less than average & 18 & 18.6 & 79 & 81.4 \\
Significantly lower than \\
average
\end{tabular}

The relative odds of engagement in tourism by gender, socio-economic status, and school performance are presented in Table 4. Engagement in tourism was not associated with gender. Children with higher socioeconomic status were 1.35 times $(p=0.037)$ more likely to engage in tourism compared to children with lower socioeconomic status. Children with above-average school performance were 1.52 times $(\mathrm{p}=0.005)$ more likely to engage in tourism compared with children with school performance that was average of below.
Table 4. Relative Odds of Engagement in Tourism with Gender, Socioeconomic Status and School Performance

\begin{tabular}{|c|c|c|c|}
\hline & 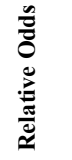 & 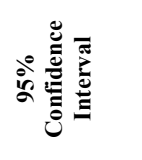 & $\mathbf{P}$ \\
\hline Gender (Male vs Female) & 1.19 & $0.90-1.56$ & 0.228 \\
\hline $\begin{array}{l}\text { Socioeconomic Status } \\
\text { (Mother's assessment: High vs } \\
\text { Low) }\end{array}$ & 1.35 & $1.02-1.78$ & 0.037 \\
\hline $\begin{array}{l}\text { School Performance (Self } \\
\text { Assessment: above average vs } \\
\text { average and below) }\end{array}$ & 1.52 & $1.13-2.05$ & 0.005 \\
\hline
\end{tabular}

Source: Authors

Adolescents who engaged in tourism were also significantly more likely to visit entertainment establishments (OR $=1.73$ [95\% CI: 1.25-2.38]); read books (2.28 [1.67-3.1]); draw/construct (2.3 [1.73 - 3.07]); play a musical instrument (2.5 [1.76 - 3.53[); play sports $(4.04$ [2.63 - 6.21]); attend theater/concerts/museums (3.74 [2.76 - 5.06]); and "socialize" using the computer (2.43 [1.53 - 3.85]).

Table 5. Engagement in Tourism and Scores on the revised Eysenck Personality Inventory

\begin{tabular}{|c|c|c|c|c|c|}
\hline \multicolumn{5}{|c|}{ Engage in Tourism } & \multirow[b]{2}{*}{$\mathrm{P}$} \\
\hline Scale & & $\begin{array}{l}\text { Often or } \\
\text { Sometime } \\
(\mathrm{n}=184)\end{array}$ & $\begin{array}{l}\text { Never } \\
(\mathrm{n}=373)\end{array}$ & $\begin{array}{l}\mathrm{t}- \\
\text { value }\end{array}$ & \\
\hline Extraversion & $\begin{array}{l}\text { Mean } \\
\text { (SD) }\end{array}$ & $\begin{array}{l}18.3 \\
(3.36)\end{array}$ & $\begin{array}{l}16.8 \\
(4.1)\end{array}$ & 4.80 & $<0.001$ \\
\hline Neuroticism & $\begin{array}{l}\text { Mean } \\
\text { (SD) }\end{array}$ & $\begin{array}{l}11.7 \\
(5.6)\end{array}$ & $\begin{array}{l}13.1 \\
(5.2)\end{array}$ & -3.00 & 0.003 \\
\hline
\end{tabular}

Source: Authors

Table 5 compares the revised Eysenck Personality Inventory scores for Extraversion and Neuroticism between adolescents who engage and do not engage in tourism. Adolescents who engage in tourism had significantly higher scores for extraversion and lower scores for neuroticism compared to adolescents who did not engage in tourism.

Table 6. Multivariable Linear Regression of Extraversion Score on Engagement in Tourism

\begin{tabular}{|c|c|c|c|}
\hline & $\operatorname{Exp}(B)$ & $95 \% \mathrm{CI}$ & $\mathbf{P}$ \\
\hline Constant & 0.042 & & 0.330 \\
\hline $\begin{array}{l}\text { Gender } \\
\quad(\text { Male }=1 ; \text { Female }=0)\end{array}$ & 1.178 & $\begin{array}{l}0.818- \\
1.696\end{array}$ & 0.379 \\
\hline Age in years & 1.030 & $\begin{array}{l}0.696- \\
1.520\end{array}$ & 0.881 \\
\hline $\begin{array}{l}\text { Socioeconomic Status } \\
\quad(\text { High }=1 ; \text { Low }=0)\end{array}$ & 1.040 & $\begin{array}{l}0.721 \\
1.500\end{array}$ & 0.833 \\
\hline $\begin{array}{l}\text { School Performance } \\
\quad(\text { Above average }=1 \\
\text { Average or below }=0)\end{array}$ & 1.265 & $\begin{array}{l}0.856 \\
1.872\end{array}$ & 0.238 \\
\hline Extraversion Score & 1.109 & $\begin{array}{l}1.054 \\
1.176\end{array}$ & $<0.001$ \\
\hline
\end{tabular}

Source: Authors 
Table 6 presents the results of multiple logistic regression of extraversion on engagement in tourism. Higher extraversion score was a significant predictor of engagement in tourism after controlling for gender, age, socioeconomic status, and school performance.

Table 7 presents the results of multiple logistic regression of neuroticism score on engagement in tourism. Lower neuroticism score was a significant predictor of engagement in tourism after controlling for gender, age, socioeconomic status, and school performance.

Table 7. Multivariable Linear Regression of Neuroticism on Engagement in Tourism

\begin{tabular}{|c|c|c|c|}
\hline & $\begin{array}{l}\operatorname{Exp(B)} \\
(95 \% \mathrm{CI})\end{array}$ & $95 \% \mathrm{CI}$ & $\mathrm{P}$ \\
\hline Constant & 0.713 & & 0.916 \\
\hline $\begin{array}{l}\text { Gender } \\
\quad(\text { Male }=1 ; \text { Female }=0)\end{array}$ & 0.977 & $\begin{array}{l}0.664 ; \\
1.437)\end{array}$ & 0.906 \\
\hline Age in years & 1.01 & $\begin{array}{l}0.687 \\
1.483\end{array}$ & 0.963 \\
\hline $\begin{array}{l}\text { Socioeconomic Status } \\
\qquad(\text { High }=1 ; \text { Low }=0)\end{array}$ & 1.074 & $\begin{array}{l}0.748 \\
1.544\end{array}$ & 0.698 \\
\hline $\begin{array}{l}\text { School Performance } \\
\quad(\text { Above average }=1 \text {; Average or } \\
\text { below }=0)\end{array}$ & 1.38 & $\begin{array}{l}0.939 \\
2.027\end{array}$ & 0.101 \\
\hline Neuroticism Score & 0.951 & $\begin{array}{l}0.917 \\
0.986\end{array}$ & 0.006 \\
\hline
\end{tabular}

Source: Authors

\section{Discussion}

In our study we found that engagement in tourism was associated with a higher extraversion score and a lower neuroticism score on the revised Eysenck Personality Inventory, after adjusting for potential confounding variables. Engagement in tourism was also associated with better school performance and higher socioeconomic status in unadjusted analyses, but not after separately including extraversion and neuroticism scores into multivariable models. Our findings on the association between extraversion and tourism behavior are consistent with most previous studies. The relationship between personality and tourism behavior is still a relatively underdeveloped field of tourism research, especially among adolescent populations (Lepp and Gibson, 2008).

The major limitations of our study are incomplete response rates on both the FCOU and supplementary EPI questionnaires; lack of detail on specific types of tourism engagement; and use of the earlier version of the Eysenck Personality Inventory compared to more recent versions of the Eysenck Personality Questionnaire. Respondent bias may occur if participants who choose to respond to specific questions differ in personality traits and/or tourism behavior compared to nonrespondents. Additionally, adolescents in our study responded to a single broad question on how they spent their leisure time, with tourism being one of the choices, rather than more detailed questions on specific types of tourism activities. The United Nations World Tourism Organization defines tourism broadly as follows: "Tourism comprises the activities of persons traveling to and staying in places outside their usual environment for not more than one consecutive year for leisure, business and other purposes." This allencompassing definition of tourism is consistent with our survey. Finally, the EPI used in our study was selected by Ukrainian adolescent psychologists because this instrument was still in wide clinical use at the time of our survey.

This study is one of the few, that we are aware of, that looks at personality and tourism behavior in a Ukrainian adolescent population. This paper is also one of the few that looks at self-reported tourism behavior in adolescents, a research population which Poria and Timothy (2013) highlight as a critical gap in the literature. While our study is a cross-sectional assessment of personality and tourism behavior in this population, the longitudinal birth cohort design allows for future analyses of life course predictors of their tourism behavior.

This study contributes to the growing body of research on personality and tourism behavior by providing data from an understudied population of Ukrainian adolescents. The implications of our findings are both theoretical and practical. Our findings are consistent with the Eysenck and Zuckerman theories of how extraversion and sensation-seeking influence tourism behavior. From a practical standpoint, understanding the associations between personality and tourism behavior can facilitate the development of tourism in Ukraine through more targeting marketing of tourism choices and services for adolescents. Even more importantly, the everyday benefits of tourism engagement, specifically among an adolescent population, should be referenced by parents, schools and governments. Our future research will continue to focus on this population and investigate how demographic, social, and personality factors affect more specific types of tourism behavior. 


\section{References}

Aluja, A., Garcia, O., \& Garcia, L.F. (2003). Relationships among extraversion, openness to experience, and sensation seeking. Personality and Individual Differences, 35, 671-680.

Eysenck, H. J., \& Eysenck, S. B. G. (1969). Personality Dimensions in Children Personality Structure and Measurement (First ed., pp. 265-316). San Diego, California: Robert Kanpp.

Eysenck, H. J. (1990). Biological dimensions of personality. In L. A. De Pervin (Ed.), Handbook of personality theory and research (pp. 246). New York: Guilford.

Lepp, A., \& Gibson, H. (2008). Sensation seeking and tourism: Tourist role, perception of risk and destination choice. Tourism Management, 29, 740750

Hoxter, A., \& Lester, D. (1987). Personality correlates of allocentrism versus psychocentrism in choice destination for travel. Psychological Reports, 60, 1138 .

Hoxter, A., \& Lester, D. (1988). Tourist behavior and personality. Personality and Individual Differences, 9, 177-178.

Hryhorczuk, N., Zvinchuk, A., Shkiriak-Nyzhnyk, Z. Gonzales, N., \& Hryhorczuk, D. (2019). Leisure activity and alcohol use among Ukrainian adolescents. Addictive Behaviors Reports, 10, 1-5.

Jackson, M. \& Inbakaran, R. (2006). Development of personality types to predict tourist behavior towards tourist product consumption. In D. Nigam \& B. George (Eds.), Tourist and Tourism (pp. 1-17). New Delhi, India: Abhijeet.

Kirkcaldy, B., \& Furnham, A. (1991). Extraversion, neuroticism, psychoticism and recreational choice. Personality and Individual Differences, 12(7), 737745 .

Leiper, N. (1995). Tourism Management. Collingwood, Victoria: TAFE Publications.

Leung, R., \& Law, R. (2010). A review of personality research in the tourism and hospitality context. Journal of Travel \& Tourism Marketing, 27, 439-459.

Li, C.-Y., Lu, S.-Y., \& Tsai, B.-K. (2015). The impact of extraversion and sensation seeking on tourist role. Society for Personality Research, 43(1), 75-84

Litvin, S. (2008). Sensation seeking and its measurement for tourism research. Journal of Travel Research, 46, 440-445.

Liu, H. (2014). Personality, leisure satisfaction, and subjective well-being of serious leisure participants. Social Behavior and Personality, 42(7), 1117-1126.

Matolin, T.V. (1998) Method of express - diagnostics of characterological traits of personality. In D.Ya. Raigorodsky (Ed.) Practical psychodiagnostics. Methods and tests. (pp.672) Samara: Publishing House "Bakhrakh".
McDonnell, I. (1994). Leisure travel to Fiji and Indonesia from Australia 1982-1992: Some factors underlying changes in market share. Unpublished master's thesis, University of Technology, Sydney, NSW.

Nickerson, N. P., (1989). "Tourism and Personality: A comparison of Two Models.” Ph.D. diss., University of Utah.

Nickerson, N. P., and G. D. Ellis (1991). "Traveler Types and Activation Theory: A Comparison of Two Models." Journal of Travel Research, 29 (Winter): 26-31.

Noyan, A. (2017). The effects of personality traits and leisure time behaviours on life satisfaction: A study of Turkish and Australian students. Paper presented at the 96th IIER Conference, Amsterdam, Netherlands, 10-15 March.

Pizam, A., Jeong, G., Reichel, A., Van Boemmel, H., Lusson, J., Steynberg, K., et al. (2004). The relationship between risk taking, sensation seeking and the tourist behavior of young adults: A cross cultural study. Journal of Travel Research, 42, 251-260.

Plog, S. (1972). Why destination areas rise and fall in popularity. The Cornell Hotel and Restaurant Administration Quarterly, 14(4), 55-58.

Poria, Y., and Timothy, D. J. (2014). Where are the children in tourism research? Annals of Tourism Research, 47, 77-95.

Poropat, A. (2011). The Eysenckian personality factors and their correlations with academic performance. British Journal of Educational Psychology, 81(1), 4158.

Roth, M., Schumacher, J., \& Brahler, E. (2005). Sensation seeking in the community. Sex, age and sociodemographic comparisons on a representative German population sample. Personality and Individual Differneces, 39, 1261-1271.

Schimmack, U., Oishi, S., Furr, R., \& Funder, D. (2004) Personality and life satisfaction: A facet-level analysis. PSPB, 30(8), 1062-1075.

Smith, S. L. J. (1990). "A Test of Plog's Allocentrism/Psychocentrism Model: Evidence from Seven Nations." Journal of Travel Research, 28 (Spring): 40-43.

Wang, W., Wu, Y.-X., Peng, Z.-G., Lu, S.-W., Yu, L., \& Wang, G.-P. (2000). Test of sensation seeking in a Chinese sample. Personality and Individual Differences, 28, 169-179.

Zuckerman, M. (1979). Sensation seeking: Beyond the optimal level of arousal. Hillsdale, NJ: Erlbaum. 